\title{
PROSES PEMECAHAN MASALAH MAHASISWA PENDIDIKAN MATEMATIKA STKIP PAMANE TALINO
}

\author{
Rahmat Winata ${ }^{1)^{*}}$ dan Rizki Nurhana Friantini ${ }^{2 \text { ) }}$ \\ 1), 2) Program Studi Pendidikan Matematika \\ STKIP Pamane Talino \\ *nata_win89@yahoo.com
}

\begin{abstract}
Abstrak
Penelitian ini bertujuan untuk mendeskripsikan mengenai proses pemecahan masalah mahasiswa Pendidikan Matematika semester 3 STKIP Pamane Talino yang memperoleh prestasi akademik tinggi, sedang, dan rendah pada mata kuliah Statistika Lanjut. Penelitian ini merupakan penelitian kualitatif. Metode penentuan subjek menggunakan purposive sampling. Teknik pengambilan data menggunakan tes dan wawancara. Validitas data menggunakan triangulasi metode. Pada penelitian ini, proses pemecahan masalah dibagi menjadi empat tahap yaitu: memahami masalah, membuat rencana, melaksanakan rencana, dan melihat kembali. Hasil dari penelitian menunjukkan bahwa mahasiswa yang memperoleh prestasi akademik tinggi sudah melaksanakan tahap-tahap pemecahan masalah dan dapat memahami masalah dengan baik tetapi belum benar-benar memahami materi sehingga hasil dari pemecahan masalah masih salah. Untuk mahasiswa yang memperoleh prestasi akademik sedang telah melaksanakan tahap-tahap pemecahan masalah tetapi belum dapat memahami soal dengan baik. Selain itu juga belum benar-benar memahami materi dan kurang teliti dalam menghitung sehingga hasil dari pemecahan masalah salah. Sedangkan untuk mahasiswa yang memperoleh prestasi akademik rendah belum dapat memahami masalah dengan baik dan belum melaksanakan tahap-tahap pemecahan masalah secara maksimal karena subjek tidak memeriksa atau melihat kembali jawaban yang ditulisnya. Selain itu juga belum memahami materi karena uji yang digunakan tidak sesuai untuk memecahkan masalah tersebut.
\end{abstract}

Kata Kunci: proses pemecahan masalah, Polya, prestasi akademik

\section{PENDAHULUAN}

Pemecahan masalah merupakan salah satu kemampuan yang penting, baik pada pembelajaran atau pada kehidupan seharihari. Khususnya pada pembelajaran matematika, kemampuan pemecahan masalah sangat diperlukan ketika memecahkan masalah-masalah matematika. Pemecahan masalah dalam matematika memberikan beberapa manfaat. NCTM 
(dalam Pellerin, 2012:2) mengungkapkan "By learning problem solving in mathematics, students should acquire way of thinking, habits of persistence and curiosity, and confidence in unfamiliar situations that will serve them outside the mathematics classroom." Kalimat tersebut bermakna dengan mempelajari pemecahan masalah dalam matematika, siswa akan belajar cara untuk berpikir, kebiasaan tekun dan ingin tahu, dan percaya diri pada situasi yang tidak dikenal yang akan dijalankan oleh mereka di luar kelas.

Masalah matematika menurut Firdaus (dalam Firdaus, 2017:502) adalah suatu tugas matematika yang aturan dalam menemukan solusinya belum diketahui oleh siswa, sehingga untuk menemukan solusi masalah matematika memerlukan pengetahuan dalam proses memikirkan masalah matematika tersebut. Oleh karena itu agar masalah-masalah matematika dapat diselesaikan sudah seharusnya kemampuan pemecahan masalah dikuasai.

Pemecahan masalah dianggap sebagai intinya matematika karena berbagai macam kegiatan matematika adalah untuk memecahkan masalah. Dengan memecahkan suatu masalah, dapat mengembangkan kemampuan dan keterampilan matematika. Kemampuan pemecahan masalah sangat penting dan merupakan salah satu dari lima standar proses matematika selain komunikasi, penalaran dan bukti, koneksi, dan representasi matematis. Menurut NCTM (dalam Firdaus, 2017:152) "problem solving means engaging in a task for which the solution method is not known in advance. In order to find a solution, students must draw on their knowledge, and through this process, they will often develop new mathematical understandings". Kalimat tersebut bermakna pemecahan masalah berarti terlibat dalam tugas yang metode solusinya tidak diketahui sebelumnya. Untuk menemukan solusi, siswa harus memanfaatkan pengetahuan mereka, dan melalui proses ini, mereka akan sering mengembangkan pemahaman matematis baru. Pemecahan masalah matematika menurut Zhu (2007:188) adalah "a complex cognitive activity" atau aktivitas kognitif yang kompleks. Sedangkan Mayer (dalam Aufin, 2012:98) mendefinisikan pemecahan masalah sebagai suatu proses banyak langkah dengan si pemecah masalah harus menemukan hubungan antara pengalaman (skema) masa lalunya dengan masalah yang sekarang dihadapinya dan kemudian bertindak untuk menyelesaikannya. Oleh karena itu pemecahan masalah merupakan aktivitas kognitif untuk menemukan solusi dari suatu masalah.

Proses pemecahan masalah bermacam-macam, salah satunya yaitu proses pemecahan masalah menurut Polya yang terdiri dari 4 kegiatan. Seperti yang disebutkan Polya (dalam Zhu, 2007:188) proses pemecahan masalah matematika terdiri dari beberapa kegiatan, yaitu memahami masalah (understanding the problem), membuat rencana (making a plan), melaksanakan rencana (carrying out the plan), dan melihat kembali (looking back). Polya (dalam Widodo dan Sudjadi, 2015:52-53) menyatakan bahwa untuk memahami suatu permasalahan dapat dilakukan dengan beberapa cara, diantaranya adalah dengan membaca berulang-ulang, menanyakan pada diri sendiri tentang apa yang ketahui, apa yang tidak diketahui, dan menanyakan tujuan dari permasalahan matematika. Untuk membuat rencana menyelesaikan permasalahan dapat dilakukan dengan mencari hubungan antara data (informasi) yang diketahui dengan yang tidak diketahui, dimungkinkan pula 
melakukan perhitungan pada variabel yang tidak diketahui tersebut. Pada tahapan melaksanakan rencana akan memeriksa tiaptiap langkah yang tertuang dalam rencana dan menuliskannya secara detail untuk memastikan bahwa tiap-tiap langkah tersebut sudah benar. Sedangkan pada tahap memeriksa kembali jawaban maka akan melihat kembali jawabannya untuk menyakinkan bahwa hasil jawaban dari permasalahan tersebut sudah benar.

Banyak penelitian yang berhubungan dengan pemecahan masalah pada mahasiswa Pendidikan Matematika. Salah satunya adalah penelitian Widodo dan Sudjadi (2015:58) yang memberikan hasil bahwa pada tahap memahami masalah sebanyak 3 mahasiswa tidak menuliskan dan menyampaikan apa yang diketahui dan ditanyakan dari masalah maka mahasiswa menjadi tidak memahami masalah. Pada tahap membuat rencana, mahasiswa keliru dalam memahami konsep tangent sudut, sehingga pada tahap kedua mahasiswa melakukan kesalahan konsep sinus, kosinus, dan tangent sudut. Pada tahap melaksanakan rencana, melakukan kesalahan dalam perhitungan. Kesalahan perhitungan yang dilakukan oleh mahasiswa dapat berupa kesalahan dalam melakukan operasi hitung dasar seperti penjumlahan, pengurangan perkalian dan pembagian. Ada juga yang melakukan kesalahan dalam membaca tabel sinus, cosinus atau tangent. Pada tahap melihat kembali, mahasiswa tidak melakukan pemeriksaan jawaban terhadap masalah.

Pada tingkat perguruan tinggi, pembelajaran matematika lebih kompleks dan membutuhkan kemampuan berpikir tingkat tinggi atau high order thinking. Sesuai pendapat Artigue dan Cornu (dalam Suryana, 2012:38) yang mengemukakan bahwa pembelajaran matematika sering dinilai negatif oleh mahasiswa dan mereka memiliki kesulitan yang cukup besar terhadap beberapa proses matematika seperti penalaran, pemecahan masalah yang tidak rutin, dan pembuktian. Kesulitan tersebut merupakan masalah bagi mahasiswa yang disebabkan adanya perubahan dari berpikir elementer ke berpikir matematis tingkat lanjut, yaitu dari mendeskripsikan ke mendefinisikan dan dari meyakinkan ke membuktikan secara logika berdasarkan pada suatu definisi. Salah satu masalah matematika pada tingkat perguruan tinggi adalah masalah pada mata kuliah Statistika Lanjut. Di STKIP Pamane Talino, Statistika Lanjut merupakan mata kuliah yang diperoleh mahasiswa Pendidikan Matematika pada semester 3. Statistika Lanjut diantaranya mempelajari mengenai uji prasyarat dan uji hipotesis. Pada penelitian ini dipilih mahasiswa Pendidikan Matematika semester 3 untuk melihat bagaimana proses pemecahan masalah pada mata kuliah Statistika Lanjut.

Sebelumnya, peneliti melakukan penelitian pendahuluan terlebih dahulu terhadap salah satu mahasiswa Pendidikan Matematika semester 3 STKIP Pamane Talino untuk melihat bagaimana proses pemecahan masalah pada mata kuliah Statistika Lanjut mengenai uji hipotesis. Hasil penelitian pendahuluan menunjukkan bahwa pada tahap awal atau tahap memahami masalah, subjek tidak dapat menyebutkan dengan benar mengenai apa yang diketahui dan yang ditunjukkan dari soal. Pada tahap membuat rencana, subjek tidak dapat menentukan dengan benar mengenai metode yang digunakan untuk menyelesaikan masalah. Pada tahap melaksanakan rencana, subjek tidak dapat memperoleh hasil yang benar karena metode yang digunakan tidak tepat. Pada tahap melihat kembali, subjek tidak dapat 
memperoleh kesimpulan karena subjek tidak dapat menyelesaikan masalah. Dari hasil penelitian pendahuluan tersebut diperoleh bahwa pemecahan masalah pada mata kuliah Statistika Lanjut merupakan salah satu masalah yang dialami oleh mahasiswa, khususnya mahasiswa Pendidikan Matematika semester 3 STKIP Pamane Talino.

Masing-masing individu berbeda dalam melakukan pemecahan masalah. Perbedaan tersebut dikarenakan masingmasing individu mempunyai karakteristik yang berbeda. Selain itu perbedaan proses pemecahan masalah juga dikarenakan adanya pengaruh dari dalam dan luar diri individu tersebut. Rasiman (2011:392) menyatakan "Ability to solve mathematics problems influenced by several factors, both internal and external factors. Internal factors include: intelligence, motivation, interests, talents, and mathematics skills as well as gender differences. External factors, such as: facilities, infrastructure, media, curriculum, teachers, learning facilities, and so on". Kalimat tersebut bermakna kemampuan memecahkan masalah matematika dipengaruhi oleh beberapa faktor, baik faktor internal maupun eksternal. Faktor internal meliputi: kecerdasan, motivasi, minat, bakat, dan keterampilan matematika serta perbedaan gender. Faktor eksternal, seperti: sarana, prasarana, media, kurikulum, guru, sarana belajar, dan sebagainya. Dari faktor-faktor tersebut yang paling mempengaruhi proses pemecahan masalah seseorang adalah faktor kecerdasan, sehingga pada penelitian ini akan diamati proses pemecahan masalah berdasarkan tingkat kecerdasan yang dimiliki yang dapat dilihat dari prestasi akademik.

Untuk mengetahui lebih lanjut mengenai pemecahan masalah mahasiswa
Pendidikan Matematika semester 3 STKIP Pamane Talino pada mata kuliah Statistika Lanjut, perlu diteliti bagaimana proses pemecahan masalah mahasiswa Pendidikan Matematika semester 3 STKIP Pamane Talino yang memperoleh prestasi akademik tinggi, sedang, dan rendah pada mata kuliah Statistika Lanjut. Diharapkan dengan menganalisis proses pemecahan masalah tidak hanya diketahui mampu atau tidak mahasiswa dalam melakukan pemecahan masalah tetapi juga dapat melihat bagaimana langkah atau proses mahasiswa ketika menghasilkan jawaban dari suatu masalah.

\section{METODE PENELITIAN}

Penelitian ini merupakan penelitian kualitatif deskriptif, yaitu mengamati proses pemecahan masalah mahasiswa Pendidikan Matematika yang memperoleh prestasi akademik tinggi, sedang, dan rendah. Penelitian ini dilakukan di Program Studi Pendidikan Matematika STKIP Pamane Talino. Pada penelitian ini subjek ditentukan dengan menggunakan purposive. Menurut Sugiyono (2010:124-125) sampling purposive adalah teknik penentuan sampel dengan pertimbangan tertentu. Dalam penelitian ini penentuan subjek dilakukan dengan cara mahasiswa Pendidikan Matematika Semester 3 dikelompokkan menjadi 3, yaitu mahasiswa yang memperoleh prestasi akademik tinggi, sedang, dan rendah. Dari pengelompokkan tersebut diambil 3 mahasiswa, yaitu 1 mahasiswa untuk masing-masing tingkat prestasi akademik

Data dalam penelitian ini berupa proses pemecahan masalah yang diperoleh dari kegiatan tes dan wawancara. Data hasil tes dan wawancara tersebut selanjutnya direduksi untuk memperoleh data terkait proses pemecahan masalah. Selanjutnya, 
dilakukan pengkategorian terhadap data hasil reduksi ke dalam tahapan proses pemecahan masalah yaitu memahami masalah, membuat rencana, melaksanakan rencana, dan melihat kembali. Untuk kepentingan keabsahan data maka dilakukan triangulasi metode pada hasil analisis data tes dan wawancara sehingga diperoleh data yang valid.

\section{HASIL DAN PEMBAHASAN}

Berdasarkan hasil analisis jawaban tes dan hasil wawancara yang dilakukan pada subjek untuk masing-masing tingkat prestasi akademik diperoleh data proses pemecahan masalah pada mata kuliah Statistika Lanjut. Data untuk masing-masing subjek pada tingkatan prestasi akademik dikategorikan menjadi 4 tahap proses pemecahan masalah yaitu tahap memahami masalah, membuat rencana, melaksanakan rencana, dan melihat kembali. Masalah yang diberikan kepada mahasiswa adalah sebagai berikut.

"Untuk menguji hipotesis bahwa metode diskusi lebih baik daripada metode ceramah, metode diskusi dikenakan kepada kelas IA dan metode ceramah dikenakan kepada kelas IB. Sebelum diberikan perlakuan itu, kedua kelas diberikan tes yang sama. Secara random dari kelas IA diambil 10 anak dan dari kelas IB diambil 12 anak. Nilai-nilai mereka adalah sebagai berikut:

\begin{tabular}{lllllllll}
\hline Kelas IA & 80 & 78 & 86 & 70 & 59 & 98 & 76 & 71 \\
& 60 & 65 & & & & & &
\end{tabular}

$\begin{array}{lllllllll}\text { Kelas IB } & 68 & 72 & 77 & 79 & 68 & 80 & 54 & 63 \\ & 89 & 74 & 66 & 86 & & & & \end{array}$

Bagaimana kesimpulan penelitian itu, jika diambil $\alpha=1 \%$ dan diasumsikan variansi populasinya sama."
Berikut ini hasil analisis tentang proses pemecahan masalah untuk masingmasing tingkat prestasi akademik.

1. Mahasiswa yang mempunyai prestasi akademik tinggi

Proses pemecahan masalah dari mahasiswa yang mempunyai prestasi akademik tinggi yaitu:

a. Tahap memahami masalah:

Dalam memahami masalah dapat disimpulkan bahwa subjek dapat memahami masalah dengan baik, karena subjek dapat menuliskan hipotesis nol $\left(\mathrm{H}_{0}\right)$ dan hipotesis alternatif $\left(\mathrm{H}_{1}\right)$ pada lembar jawab dengan benar sesuai dengan pertanyaan yang ada pada soal. Selain itu, subjek menuliskan informasi yang ada pada soal dengan benar.

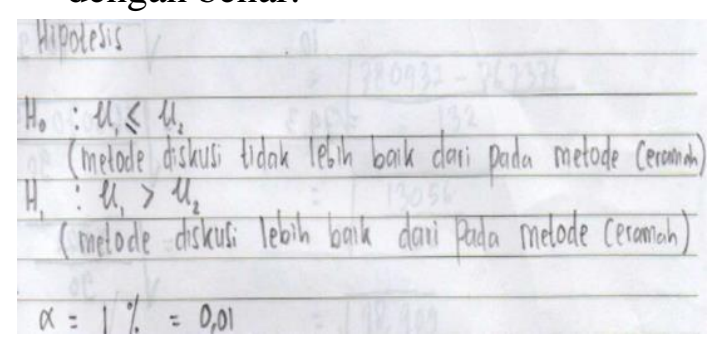

b. Tahap membuat rencana:

Pada tahap ini, subjek membuat rencana mengenai uji yang akan digunakan untuk menjawab masalah dengan benar yaitu dengan uji-t untuk variansi populasi sama. Subjek menuliskan rumus uji-t dengan benar dan lengkap.

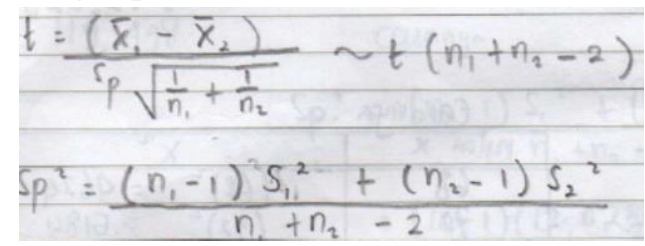

c. Tahap melaksanakan rencana:

Pada tahap melaksanakan rencana, subjek menerapkan uji-t sesuai dengan perencanaan di awal. Subjek menghitung rata-rata dan 
standar deviasi untuk masingmasing kelas dengan benar. Subjek dapat menerapkan uji-t dengan benar yaitu dengan melakukan operasi hitung penjumlahan, pengurangan, perkalian, pembagian, pengkuadratan, dan pengakaran.

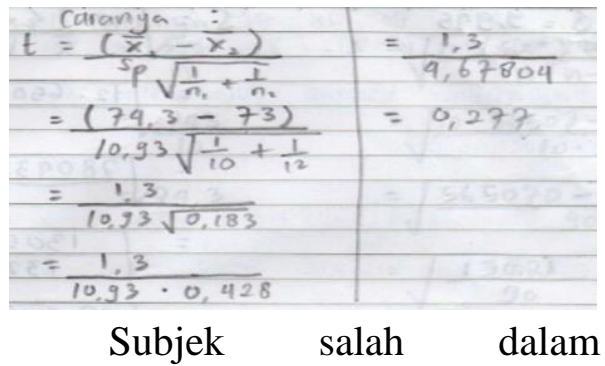
menentukan daerah kritik, sehingga salah dalam menentukan keputusan uji. Keputusan uji yang dihasilkan subjek yaitu $\mathrm{H}_{0}$ diterima padahal seharusnya $\mathrm{H}_{0}$ ditolak.

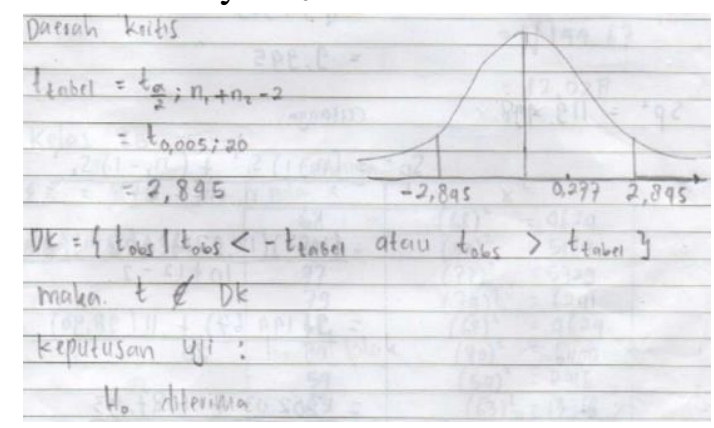

d. Tahap melihat kembali:

$$
\text { Pada tahap ini, subjek }
$$
memeriksa dengan melihat kembali proses perhitungan yang dilakukan dan yakin bahwa jawabannya telah benar. Tetapi subjek tidak menyadari kesalahan yang dilakukan pada saat menentukan daerah kritik sehingga kesimpulan yang dihasilkan subjek pada uji tersebut salah.

2. Mahasiswa yang mempunyai prestasi sedang

Proses pemecahan masalah dari mahasiswa yang mempunyai prestasi akademik sedang yaitu: a. Tahap memahami masalah:

Pada tahap memahami masalah, subjek menuliskan informasi yang ada pada soal dengan benar. Tetapi subjek salah ketika menuliskan hipotesis nol $\left(\mathrm{H}_{0}\right)$ dan hipotesis alternatif $\left(\mathrm{H}_{1}\right)$ pada lembar jawab karena tidak sesuai dengan pertanyaan yang ada pada soal. Oleh karena itu disimpulkan subjek belum dapat memahami masalah.

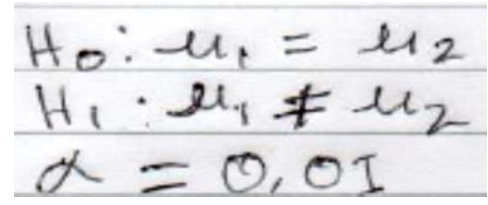

b. Tahap membuat rencana:

Pada tahap ini, subjek membuat rencana mengenai uji yang akan digunakan untuk menjawab hipotesis dengan benar yaitu dengan uji-t untuk variansi populasi sama. Subjek menuliskan rumus uji-t dengan benar dan lengkap.

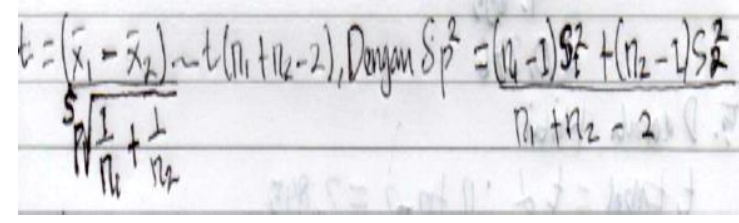

c. Tahap melaksanakan rencana:

Pada tahap melaksanakan rencana, subjek menerapkan uji-t sesuai dengan rencana di awal. Subjek benar pada saat menghitung rata-rata masing-masing kelas, tetapi salah saat menghitung standar deviasi. Subjek menerapkan uji-t dengan melakukan operasi hitung penjumlahan, pengurangan, perkalian, pembagian, pengkuadratan, dan pengakaran tetapi tidak mendapatkan hasil yang benar karena kesalahan pada 
penghitungan standar deviasi di awal.

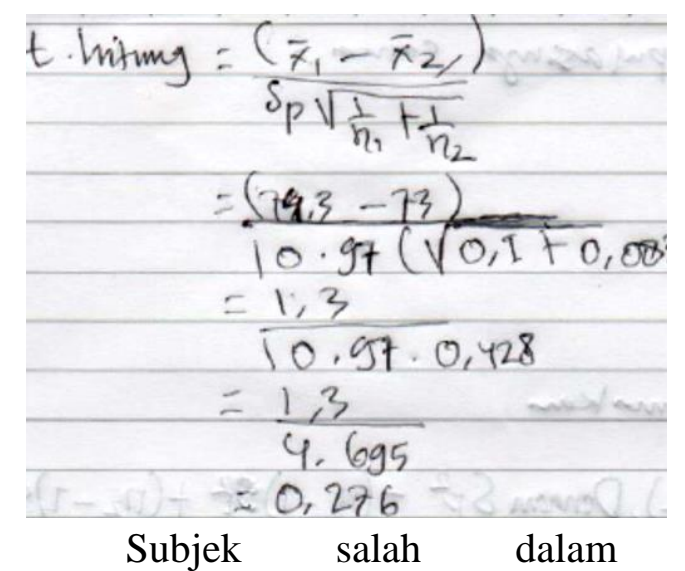

menentukan daerah kritik, sehingga salah dalam menentukan keputusan uji. Keputusan uji yang dihasilkan subjek yaitu $\mathrm{H}_{0}$ diterima padahal seharusnya $\mathrm{H}_{0}$ ditolak.

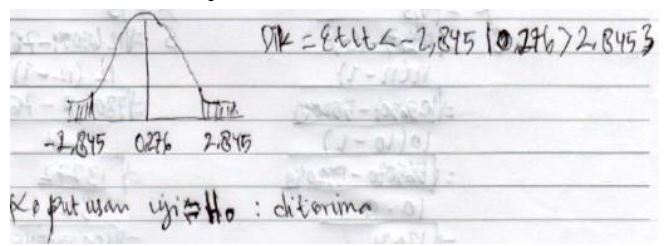

d. Tahap melihat kembali:

Pada tahapan ini, subjek memeriksa dengan melihat kembali proses perhitungan yang dilakukan dan yakin bahwa jawabannya telah benar. Subjek tidak menyadari kesalahan yang dilakukan pada saat menghitung standar deviasi, subjek tidak teliti dalam melakukan perhitungan. Subjek salah dalam membuat kesimpulan.

3. Mahasiswa yang mempunyai prestasi rendah

Proses pemecahan masalah dari mahasiswa yang mempunyai prestasi akademik rendah yaitu:

a. Tahap memahami masalah:

$$
\begin{aligned}
& \text { Pada tahap memahami } \\
& \text { masalah, subjek menuliskan } \\
& \text { informasi yang ada pada soal } \\
& \text { dengan benar. Subjek salah ketika }
\end{aligned}
$$

menuliskan hipotesis nol $\left(\mathrm{H}_{0}\right)$ dan hipotesis alternatif $\left(\mathrm{H}_{1}\right)$ pada lembar jawab karena tidak sesuai dengan pertanyaan yang ada pada soal. Dapat disimpulkan, subjek belum dapat memahami masalah.

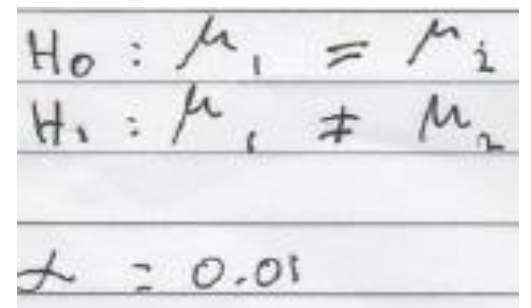

b. Tahap membuat rencana:

Dalam membuat rencana pemecahan, subjek salah mengenai uji yang akan digunakan untuk menyelesaikan masalah karena subjek menerapkan uji-t untuk variansi populasi tak sama seharusnya uji-t untuk variansi populasi sama.

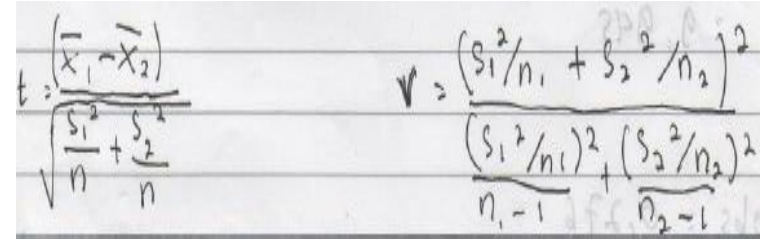

c. Tahap melaksanakan rencana:

Pada pelaksanaan rencana, subjek menganalisis sesuai dengan yang direncanakan yaitu menggunakan uji-t untuk variansi populasi tak sama. Subjek benar pada saat menghitung rata-rata dan standar deviasi untuk masingmasing kelas. Subjek menerapkan uji-t untuk variansi populasi tak sama dengan melakukan operasi hitung penjumlahan, pengurangan, pembagian, pengkuadratan, dan pengakaran. Walaupun hasil perhitungan uji-t benar jawaban mahasiswa tetap salah karena uji yang digunakan tidak sesuai untuk menjawab masalah. 


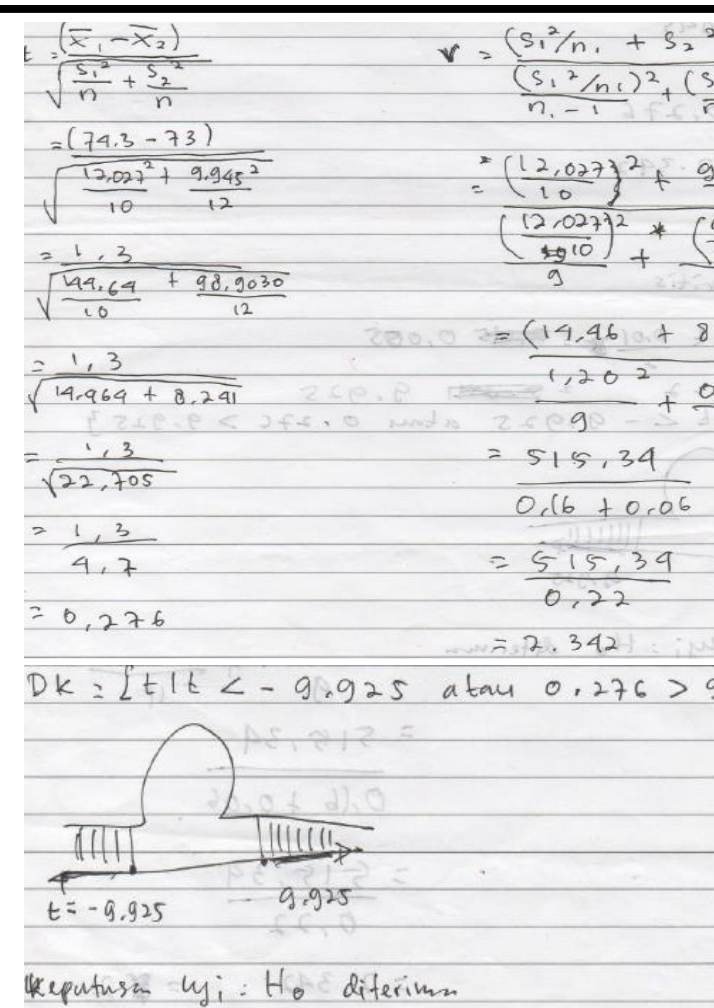

d. Tahap melihat kembali:

Ketika tahapan memeriksa kembali, subjek tidak memeriksa kembali jawaban yang ditulis dan tidak yakin dengan jawabannya. Subjek tidak memahami kesalahan uji yang dilakukan.

\section{SIMPULAN}

Berdasarkan hasil analisis data dan pembahasan diperoleh simpulan sebagai berikut. Proses pemecahan masalah mahasiswa Pendidikan Matematika Semester 3 STKIP Pamane Talino yang mempunyai prestasi akademik tinggi pada Mata Kuliah Statistika Lanjut yaitu dapat memahami masalah dengan baik yaitu dengan menuliskan informasi dan hipotesis sesuai dengan soal. Mahasiswa dapat membuat rencana dengan baik yaitu dengan menuliskan metode uji yang akan digunakan dengan benar. Mahasiswa dapat melaksanakan rencana dengan baik yaitu dengan melakukan perhitungan dengan kritik sehingga tidak tepat dalam menentukan keputusan. Oleh karena itu kesimpulan yang diambil juga tidak tepat. Tahap selanjutnya, mahasiswa melihat kembali jawaban yang telah ditulisnya. Apabila dilihat dari proses pemecahan masalah yang dilakukan, mahasiswa sudah melaksanakan tahap-tahap pemecahan masalah dan dapat memahami masalah dengan baik tetapi belum benar-benar memahami materi sehingga hasil dari pemecahan masalah salah.

Proses pemecahan masalah mahasiswa Pendidikan Matematika Semester 3 STKIP Pamane Talino yang mempunyai prestasi akademik sedang pada Mata Kuliah Statistika Lanjut yaitu belum dapat memahami masalah dengan baik, walaupun dapat menuliskan informasi soal dengan benar tetapi pembuatan hipotesis salah tidak sesuai dengan soal. Mahasiswa dapat membuat rencana dengan baik yaitu dengan menuliskan metode yang akan digunakan dengan benar. Tetapi mahasiswa belum dapat melaksanakan rencana dengan baik karena perhitungan yang dilakukan salah. Menentukan daerah kritik juga salah sehingga tidak tepat dalam menentukan keputusan. Oleh karena itu kesimpulan yang diambil juga tidak tepat. Selanjutnya mahasiswa melihat kembali jawabannya. Apabila dilihat dari proses pemecahan masalah yang dilakukan dapat disimpulkan mahasiswa belum dapat memahami soal dengan baik. Selain itu juga belum benarbenar memahami materi dan kurang teliti dalam menghitung sehingga hasil dari pemecahan masalah salah.

Proses pemecahan masalah mahasiswa Pendidikan Matematika Semester 3 STKIP Pamane Talino yang mempunyai prestasi akademik rendah pada Mata Kuliah Statistika Lanjut yaitu belum dapat memahami soal dengan baik walaupun 
menuliskan informasi dengan benar sesuai soal tetapi hipotesis yang dibuat salah. Mahasiswa belum dapat membuat rencana dengan baik karena metode yang akan digunakan salah sehingga tidak tepat dalam menentukan keputusan. Oleh karena itu kesimpulan yang diambil juga tidak tepat. Selanjutnya, mahasiswa juga tidak melihat kembali jawabannya. Apabila dilihat dari proses pemecahan masalah yang dilakukan, mahasiswa belum memahami masalah dengan baik dan belum dapat melaksanakan tahap-tahap pemecahan masalah secara maksimal. Selain itu juga belum memahami materi karena metode yang digunakan tidak sesuai untuk memecahkan masalah tersebut.

Berdasarkan simpulan di atas, saran dari penelitian ini adalah sebagai berikut. 1) Berdasarkan hasil penelitian ini proses pemecahan masalah yang dilakukan mahasiswa ternyata berbeda-beda, sehingga untuk mengembangkan atau melakukan penelitian terkait dapat dilakukan pada subjek yang memiliki karakteristik yang berbeda dari penelitian ini. 2) Dosen dapat menggunakan metode pembelajaran yang efektif selain pembelajaran klasikal seperti metode problem solving, sehingga lebih membantu mahasiswa yang memperoleh prestasi akademik rendah dan sedang dalam melakukan pemecahan masalah, melakukan pendekatan kepada mahasiswa yang memperoleh prestasi akademik rendah agar lebih teliti dalam melakukan perhitungan, memberikan pemahaman mengenai uji hipotesis dan uji-t kepada mahasiswa yang memperoleh prestasi akademik sedang dan rendah, dan sering memberikan latihan soal kepada mahasiswa yang memperoleh prestasi akademik tinggi, sedang, dan rendah sehingga dapat membantu mengembangkan proses pemecahan masalah.

\section{DAFTAR PUSTAKA}

Aufin, Mohammad. 2012. "Komunikasi dan Pemecahan Masalah dalam Pembelajaran Matematika". Jurnal Psikologi. Vol. 1, No. 2, Hal 94-110, Agustus 2012.

Firdaus, Hana Puspita Eka. 2017. “Analisis Kesalahan Mahasiswa dalam Menyelesaikan Masalah Matematika Berdasarkan Gaya Belajar". Prosiding Konferensi Nasional Penelitian Matematika dan Pembelajarannya II (KNPMP II) Universitas Muhammadiyah Surakarta. Surakarta: 18 Maret 2017.

Pellerin, J. E. 2012. "Improving Mathematical Reasoning and Discourse trough Problem Solving". University of South Florida St. Petersburg Student Research Journal. Vol. 2, Issue 1, Pp. 1-14.

Rasiman. 2011. "Leveling Of Students Critical Thinking Abilities In Mathematics Problem Solving In Line With Gender Differences". Prosiding International Seminar and the Fourth National Conference on Mathematics Education 2011 "Building the Nation Character through Humanistic Mathematics Education”. Department of Mathematics Education, Yogyakarta State University. Yogyakarta: 21-23 Juli 2011.

Sugiyono. 2010. Metode Penelitian Pendidikan Pendekatan Kuantitatif, Kualitatif, dan R\&D. Bandung: Alfabeta. 
Suryana, A. 2012. "Kemampuan Berpikir Matematis Tingkat Lanjut (Advanced Mathematical Thinking) dalam Mata Kuliah Statistika Matematika 1". Prosiding Seminar Nasional Matematika dan Pendidikan Matematika FMIPA Universitas Negeri Yogyakarta. Yogyakarta: 10 November 2012.

Widodo, Sri Adi dan Sujadi, A. A. 2015. “Analisis Kesalahan Mahasiswa dalam Memecahkan Masalah Trigonometri”. Jurnal Sosiohumaniora. Vol. 1, No. 1, April 2015.

Zhu, Z. 2007. "Gender Differences in Mathematical Problem Solving Patterns: A Review of Literature". International Education Journal. Vol. 8, No. 2, Pp. 187-203. ISSN: 14431475 . 